\title{
Metacarpal Fractures: Current Concepts of Management
}

\author{
*Elalfy M Mohamed \\ Orthopedic Surgeon, Mansoura University Hospital, Egypt
}

Submission: September 29, 2017; Published: October 13, 2017

*Corresponding author: Elalfy M Mohamed, Faculty of Medicine, Orthopaedic surgery resident at Mansoura University Hospitals, Egypt, Email: elalfy2299@gmail.com

\section{Introduction}

Epidemiology: Metacarpal fractures comprise between 18-44 \% of all hand fractures. Non-thumb metacarpals account for around $88 \%$ of all metacarpal fractures, with the fifth finger most commonly involved [1-3] (Figure 1).

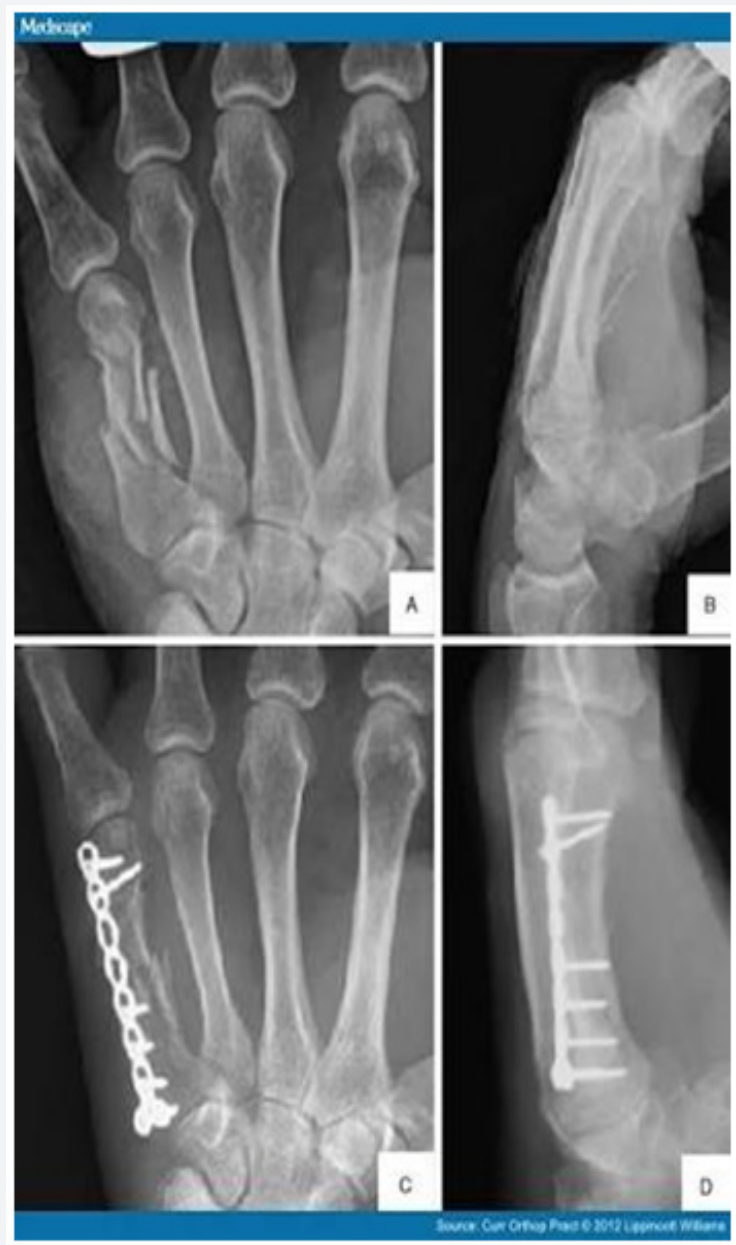

Figure 1: Non-thumb metacarpals account for around $88 \%$ of all metacarpal fractures, with the fifth finger most commonly involved.
Mechanism of Injury: Most metacarpal fractures occur in the active and working population, particularly adolescents and young adults and usually result from a direct blow, crush, or missile injury. Trauma to the hand is common, frequently resulting in metacarpal, fractures and dislocations head $[3,4]$.

Symptoms and Examination Findings: Prominent swelling, decreased range of motion, and tenderness is found at the metacarpophalangeal (MCP) joint. Axial load to the MCP joint worsens pain (Figure 2).

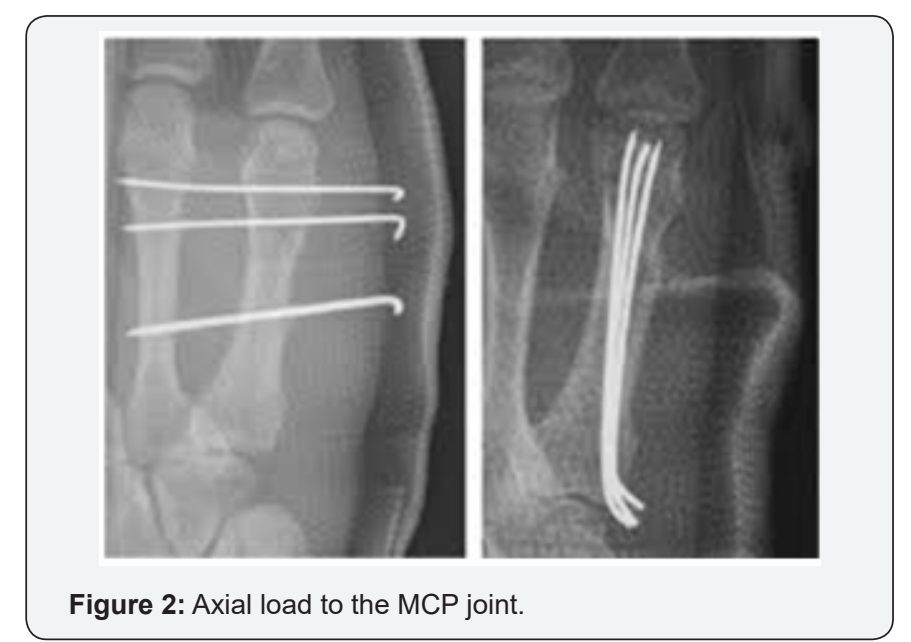

\section{Treatment Options}

Appropriate treatment includes adequate assessment, physical examination, and directed imaging. Such an approach should lead to a rational plan that focuses on the rehabilitation of all damaged components, including osseous, articular, and soft tissue structures [5,6]. Management of non-thumb metacarpal shaft fracture is depending on the stability and personality of the fracture. Undisplaced fracture with any fracture configuration can be managed by conservative method with a slab or a splint immobilizing the wrist in extension and MP joint in flexion greater than $70^{\circ}$ (Clam digger slab/cast), allowing early IP mobilization [7-11]. 


\section{Indications for Operative Treatment Include the} Following

i. Failure to achieve or maintain acceptable reduction using closed techniques

ii. Open fractures.

iii. Multiple hand fractures.

iv. Displaced intra-articular fractures.

v. Fractures with severe soft-tissue loss requiring a stable skeleton (Figure 3).

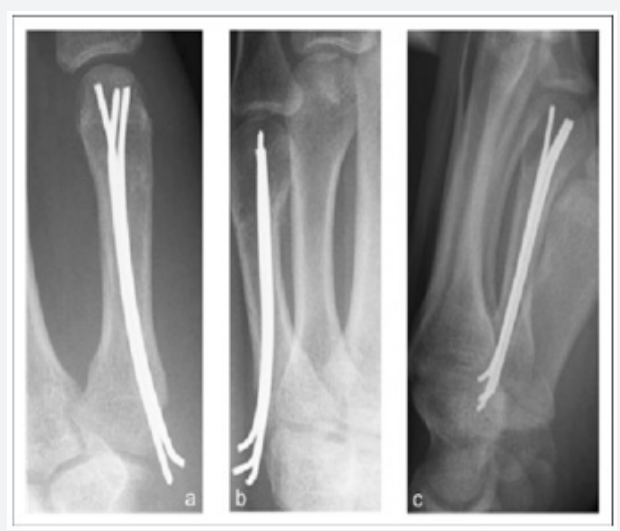

Figure 3: Operative method Bouquet Pinning of a small finger metacarpal neck fracture.

Many surgical options have been described to treat metacarpal shaft fractures [12-14] with no consensus on optimal technique. Options include open reduction internal fixation (with various configurations described), Kirschner (K-) wire fixation (with multiple described techniques), suture fixation, and cerclage wiring. Percutaneous pinning with Kirschner wires is an attractive option, as extensive surgical dissection soft tissue devitalisation at the fracture site can be avoided. It also limits the potential complication of extensor irritation by a dorsal plate, lessening the chance of extensor tenosynovitis, although this complication has still been reported with K-wire fixation. Described methods include the bouquet technique, ante grade and retrograde intramedullary placement, locking techniques and transverse pinning to adjacent metacarpals $[13,14]$.

A study of bouquet pinning versus transverse pinning did not demonstrate differences in outcomes, but the authors recommended bouquet pinning with buried wires. A study utilizing trans-verse pinning of MC shaft fractures demonstrated improved maintenance of reduction of the fracture with two distal pins and one proximal pin over one distal and one proximal pin. A single K-wire can be used with intramedullary technique for transverse or short oblique angulated fractures while long oblique or rotationally malaligned fractures require more fixations to control the deformities [15]. Plate and screw fixation does appear to lead to good functional results $[16,17]$ Varying plating methods can be used from non-locking to locking.

\section{Outcomes}

Outcomes are generally positive with various reporting methods, including the Disabilities of the Arm, Shoulder, and Hand (DASH) scoring system. Reported excellent or good outcomes range from $78 \%$ to $94 \%$ [18-20]. There does appear to be predictable healing of these fractures with rates as high as 90 to $100 \%$. Osseous union typically occurs between five and eight weeks. Non-operative treatment results in predictable healing rates as well with one study showing $100 \%$ union of 54 fractures in a retrospective review of treatment with palmar wrist splints and mobilization of all fingers [21,22]. Percutaneous pinning has good outcomes with up to $100 \%$ bony union rates. One study of retrograde K-wire fixation in 105 patients with 10 month follow-up showed the same ROM as non-injured side. Plate and screw fixation leads to $78-85 \%$ acceptable to excellent function $[23,24]$.

\section{Complications}

Despite predictable healing and excellent or good outcomes, surgical procedures can lead to complications. The most common complications include superficial infections, extensor tenosynovitis, stiffness, hardware failure, and sensory disturbances (cold intolerance as well as complex regional pain syndrome) [25-27]. Prevention of disability from hand injuries is the primary goal of treatment. Maintenance of function rather than cosmesis is of paramount concern in the management of hand injuries.

\section{Conclusion}

Metacarpal fractures of the hand are common injuries and can cause significant disability if not treated properly. Not all fractures require surgical intervention, as good outcomes have been reported with conservative care. $\mathrm{K}$ wire fixation as well as open reduction and internal fixation are acceptable methods to treat MC shaft fractures. Lag screws for long oblique fractures provides good fixation. Outcomes appear to be good regardless of surgical technique, with high rates of union. Surgical treatment is not without complications and these should be elucidated to patients before proceeding with any treatment option. Until foreign body reactions can be eliminated, we recommend against the use of absorbable implants at this time. Randomized prospective studies are needed to help determine appropriate indications for the surgical treatment of metacarpal shaft fractures, as well as guide best treatment options.

\section{References}

1. Kollitz KM, Hammert WC, Vedder NB, Huang JI (2014) Metacarpal fractures: treatment and complications. Hand 9(1): 16-23.

2. Chung KC, Spilson SV (2001) The frequency and epidemiology of hand and forearm fractures in the United States. J Hand Surg 26: 908-915.

3. Gudmundsen TE, Borgen L (2009) Fractures of the fifth metacarpal. Acta Radiol 50(3): 296-300.

4. Bloom JM, Hammert WC (2014) Evidence-based medicine: Metacarpal fractures. Plast Reconstr Surg 133(5):1252-1260. 
5. Chinchalkar SJ, Gan BS (2003) Management of proximal interphalangeal joint fractures and dislocations. J Hand Ther 16: 117-128.

6. Ali H, Rafique A, Bhatti M, Ghani S, Sadiq M, Beg SA (2007) Management of fractures of metacarpals and phalanges and associated risk factors for delayed healing. J Pak Med Assoc 57(2): 64-67.

7. Kamath JB, Naik DM, Bansal A (2011) Current concepts in managing fractures of metacarpal and phalangess. Indian Journal of Plastic Surgery 44(2): 203-211.

8. Wilson RL, Carter MS (1978) Management of hand fractures. In: Hunter JM, Schneider LH, Mackin EJ, Callahan AD, editors. Rehabilitation of the Hand. CV Mosby, St. Louis, USA, pp. 180-194.

9. Flatt AE (1972) Fractures: The Care of Minor Hand Injuries. (3 $3^{\text {rd }}$ edn.), CV Mosby, St. Louis, USA.

10. Simonetta C (1970) The use of "A.0." plates in the hand. Hand 2(1): 43-45.

11. Kumar VP, Satku K (1995) Surgical management of osteochondral fractures of the phalanges and metacarpals: A surgical technique. J Hand Surg Am 20(6): 1028-1031.

12. Al-Qattan MM (2008) Outcome of conservative management of spiral/ long oblique fractures of the metacarpal shaft of the fingers using a pal-mar wrist splint and immediate mobilisation of the fingers. J Hand Surg Eur Vol 33(6): 723-727.

13. Dona E, Gillies RM, Gianoutsos MP, Walsh WR (2004) Plating of metacarpal fractures: unicortical or bicortical screws? J Hand Surg Br 29(3): 218-221.

14. Itadera E, Hiwatari R, Moriya H, Ono Y (2008) Closed intramedullary fixation for metacarpal fractures using J-shaped nail. Hand Surg 13(3): 139-145.

15. Konradsen L, Nielsen PT, Albrecht-Beste E (1990) Functional treatment of metacarpal fractures 100 randomized cases with or without fixation. Acta Orthop Scand 61(6): 531-534.

16. Bannasch H, Heermann AK, Iblher N, Momeni A, Schulte-Monting J, et al. (2010) Ten years stable internal fixation of metacarpal and pha-langeal hand fractures-risk factor and outcome analysis show no increase of complications in the treatment of open compared with closed fractures. J Trauma 68(3): 624-628.
17. Windolf J, Rueger JM, Werber KD, Eisenschenk A, Siebert H, et al. (2009) Treatment of metacarpal fractures. Recommendations of the Hand Surgery Group of the German Trauma Society. Unfallchirurg. 112(6): 577-588.

18. Liporace FA, Kinchelow T, Gupta S, Kubiak EN, McDonnell M (2008) Minifragment screw fixation of oblique metacarpal fractures: a biomechanical analysis of screw types and techniques. Hand (N Y) 3(4): 311315.

19. Souer JS, Mudgal CS (2008) Plate fixation in closed ipsilateral multiple metacarpal fractures. J Hand Surg Eur Vol 33(6): 740-744.

20. Nalbantoglu U, Gereli A, Ucar BY, Kocaoglu B, Dogan T (2008) Treatment of metacarpal fractures with open reduction and low-profile plate and screw fixation. Acta Orthop Traumatol Turc 42(5): 303-309.

21. Wills BP, Crum JA, McCabe RP, Vanderby R, Ablove RH (2013) The effect of metacarpal shortening on digital flexion force. J Hand Surg Eur Vol 38(6): 667-672.

22.Zirgibel BJ, Macksoud WS (2013) Self-correcting intramedullary Kirschner wire fixation of metacarpal shaft fractures. Tech Hand Up Extrem Surg 17(2): 87-90.

23. Mumtaz MU, Farooq MA, Rasool AA, Kawoosa AA, Badoo AR, et al. (2010) Unstable metacarpal and phalangeal fractures: treatment by internal fixation using $\mathrm{AO}$ mini-fragment plates and screws. Ulus Travma Acil Cerrahi Derg 16(4): 334-338.

24. Gajendran VK, Szabo RM, Myo GK, Curtiss SB (2009) Biomechanical comparison of double-row locking plates versus single- and doublerow non-locking plates in a comminuted metacarpal fracture model. J Hand Surg Am 34(10): 1851-1858.

25. Zhang LS, Pan YW, Tian GL, Li WJ, Xia SH, et al. (2010) Biomechanical research of antegrade intramedullary fixation for the metacarpal fractures. Zhonghua Wai Ke Za Zhi 48(8): 606-609.

26. Lionelli GT, Korentager RA (2002) Biomechanical failure of metacarpal fracture resorbable plate fixation. Ann Plast Surg 49(2): 202-206.

27. Fusetti C, Meyer H, Borisch N, Stern R, Santa DD, et al. (2002) Complications of plate fixation in metacarpal fractures. J Trauma 52(3): 535-539.

\section{Your next submission with Juniper Publishers will reach you the below assets}

- Quality Editorial service

- Swift Peer Review

- Reprints availability

- E-prints Service

- Manuscript Podcast for convenient understanding

- Global attainment for your research

- Manuscript accessibility in different formats

( Pdf, E-pub, Full Text, Audio)

- Unceasing customer service

Track the below URL for one-step submission https://juniperpublishers.com/online-submission.php 